\title{
The Role of Mitochondria in Cellular Iron-Sulfur Protein Biogenesis: Mechanisms, Connected Processes, and Diseases
}

\author{
Oliver Stehling ${ }^{1}$ and Roland Lill ${ }^{1,2,3}$ \\ ${ }^{1}$ Institut für Zytobiologie, Philipps-Universität Marburg, 35032 Marburg, Germany \\ ${ }^{2}$ Max-Planck-Institut für Terrestrische Mikrobiologie, 35043 Marburg, Germany \\ ${ }^{3}$ LOEWE Zentrum für Synthetische Mikrobiologie SynMikro, 35043 Marburg, Germany \\ Correspondence: lill@staff.uni-marburg.de
}

\begin{abstract}
Iron-sulfur (Fe/S) clusters belong to the most ancient protein cofactors in life, and fulfill functions in electron transport, enzyme catalysis, homeostatic regulation, and sulfur activation. The synthesis of $\mathrm{Fe} / \mathrm{S}$ clusters and their insertion into apoproteins requires almost 30 proteins in the mitochondria and cytosol of eukaryotic cells. This review summarizes our current biochemical knowledge of mitochondrial $\mathrm{Fe} / \mathrm{S}$ protein maturation. Because this pathway is essential for various extramitochondrial processes, we then explain how mitochondria contribute to the mechanism of cytosolic and nuclear Fe/S protein biogenesis, and to other connected processes including nuclear DNA replication and repair, telomere maintenance, and transcription. We next describe how the efficiency of mitochondria to assemble $\mathrm{Fe} / \mathrm{S}$ proteins is used to regulate cellular iron homeostasis. Finally, we briefly summarize a number of mitochondrial "Fe/S diseases" in which various biogenesis components are functionally impaired owing to genetic mutations. The thorough understanding of the diverse biochemical disease phenotypes helps with testing the current working model for the molecular mechanism of $\mathrm{Fe} / \mathrm{S}$ protein biogenesis and its connected processes.
\end{abstract}

\begin{abstract}
M itochondria perform crucial roles in many biochemical processes. They generate ATP by oxidative phosphorylation and participate in numerous metabolic pathways such as citric acid cycle, fatty acid degradation, urea cycle, and the biosynthesis of lipids and amino acids. Moreover, the organelles are involved in the biosynthesis of various protein cofactors such as heme, Moco, biotin, lipoic acid, and, last but not least, iron-sulfur (Fe/S) clusters. Fe/S clusters are ancient protein cofactors, and they are
\end{abstract}

involved in electron transfer reactions, participate in catalytic and regulatory processes, and serve as sulfur donors during the synthesis of lipoic acid and biotin (Beinert et al. 1997). The most common and simplest forms of Fe/S clusters are of the [2Fe-2S] and [4Fe-4S] type, but also [3Fe-4S] forms or more complex clusters containing additional heavy metal ions are known ( $\mathrm{Hu}$ and Ribbe 2012; Peters and Broderick 2012). The Fe ion of the cluster is typically coordinated by the sulfur of protein-

Editors: Douglas C. Wallace and Richard J. Youle

Additional Perspectives on Mitochondria available at www.cshperspectives.org

Copyright (C) 2013 Cold Spring Harbor Laboratory Press; all rights reserved; doi: 10.1101/cshperspect.a011312

Cite this article as Cold Spring Harb Perspect Biol 2013;5:a011312 
bound cysteine residues or the nitrogen of histidine residues, but in rare cases other amino acid residues or cofactors such as $S$-adenosylmethionine (SAM) are used as coordinating ligands (Lanz and Booker 2012).

Despite the chemical simplicity of Fe/S clusters their biosynthesis is rather complicated and requires more than two dozen components in eukaryotes (for detailed previous reviews see Lill and Mühlenhoff 2008; Lill 2009; Stemmler et al. 2010; Alfonzo and Lukes 2011; Balk and Pilon 2011; Lill et al. 2012; Rouault 2012). The pathway is initiated by the mitochondrial ironsulfur cluster (ISC) assembly machinery, which comprises more than 15 components (Fig. 1). The core of this machinery is required not only for the biosynthesis of $\mathrm{Fe} / \mathrm{S}$ proteins inside but also outside mitochondria. Maturation of these latter $\mathrm{Fe} / \mathrm{S}$ proteins is assisted by the cytosolic iron-sulfur protein assembly (CIA) machinery consisting of eight known proteins (Lill 2009;
Sharma et al. 2010). The function of the CIA machinery and some of its components strictly depends on the core mitochondrial ISC assembly system, which serves as a sulfur donor for extramitochondrial $\mathrm{Fe} / \mathrm{S}$ protein maturation (Fig. 1). A still unknown sulfur-containing compound is generated by the ISC assembly system and exported by the mitochondrial $\mathrm{ABC}$ transporter Atm1 (human ABCB7) to the cytosol for use in the CIA system.

In eukaryotes, known $\mathrm{Fe} / \mathrm{S}$ proteins are located in mitochondria, cytosol, and nucleus where they perform rather diverse functions (Fig. 1). In mitochondria they are involved in the TCA cycle (aconitase), the electron transfer chain (respiratory complexes I-III), fatty acid oxidation (ETF-ubiquinone oxidoreductase), and in lipoate and biotin biosynthesis (lipoate and biotin synthases). In the cytosol, Fe/S proteins function in amino acid biosynthesis (isopropylmalate isomerase), tRNA modification

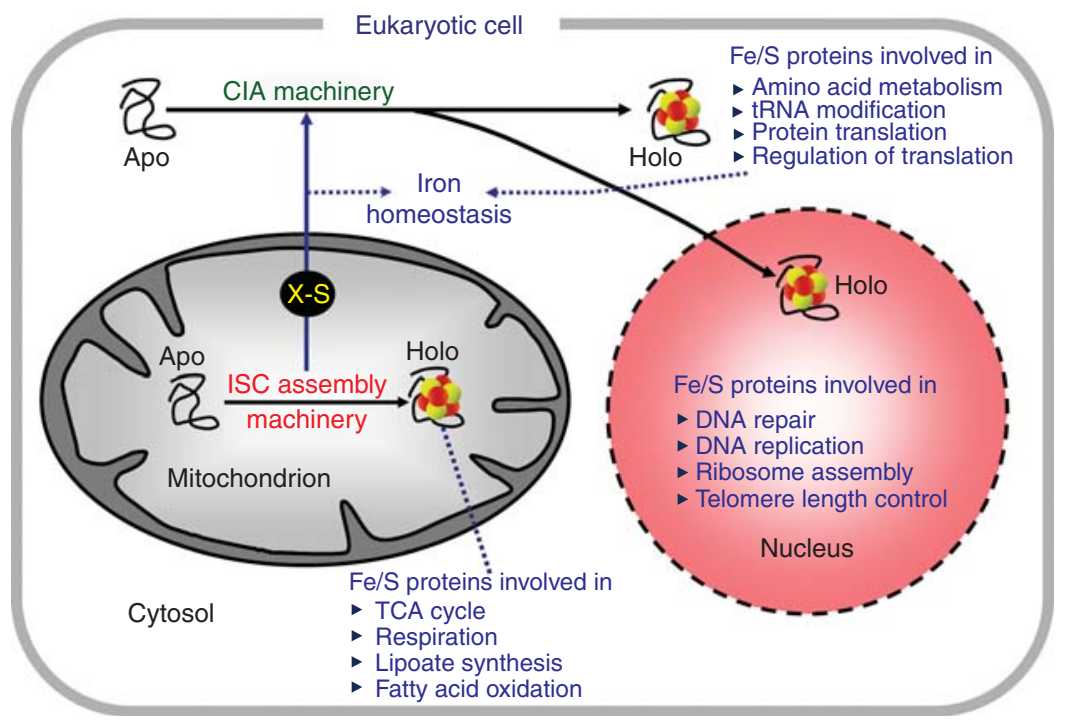

Figure 1. The biogenesis of cellular $\mathrm{Fe} / \mathrm{S}$ proteins in eukaryotes and the links to cellular iron homeostasis, protein translation, and nuclear genome integrity. Eukaryotic Fe/S proteins are located in mitochondria, cytosol, and nucleus where they perform diverse functions in cellular metabolism and regulation. The mitochondrial $\mathrm{Fe} / \mathrm{S}$ cluster (ISC) assembly machinery matures all organellar Fe/S proteins, and additionally contributes to the biogenesis of cytosolic and nuclear Fe/S proteins by producing an unknown sulfur-containing compound (X-S) that is exported to the cytosol and used by the cytosolic Fe/S protein assembly (CIA) machinery. Hence, mitochondria are directly responsible for the essential functions (e.g., of nuclear $\mathrm{Fe} / \mathrm{S}$ proteins involved in DNA metabolism and genome maintenance). Additionally, the ISC assembly machinery exerts a regulatory role on cellular iron homeostasis (see text for details). Red and yellow circles indicate iron and sulfur ions, respectively. 
(e.g., Tyw1 generating the wybutosine base), posttranscriptional regulation of iron metabolism (iron regulatory protein 1 ), or ribosomal protein translation (ABC protein Rli1, aka ABCE1). Important nuclear Fe/S proteins participate in DNA replication (DNA polymerases and primases) and DNA repair or telomere length regulation (ATP-dependent DNA helicases) (Lill and Mühlenhoff 2008; Lill et al. 2012). It can readily be seen from the scheme in Fig. 1 that mitochondria play a crucial role in the biogenesis of a number of extramitochondrial Fe/S proteins that are essential for life such as those involved in DNA maintenance and protein translation. Because without these proteins any eukaryotic cell is unviable, this provides a satisfactory explanation for the essential character of mitochondria within the cell, and shows that mitochondrial function in $\mathrm{Fe} / \mathrm{S}$ protein biogenesis directly affects nuclear function in gene expression.

Failure to assemble Fe/S proteins is associated with severe and frequently fatal neurodegenerative, metabolic, or hematological diseases (Camaschella et al. 2007; Calvo et al. 2010; Sheftel et al. 2010a; Cameron et al. 2011; NavarroSastre et al. 2011; Rouault 2012). The founding example of an "Fe/S disease" is Friedreich's ataxia, which is characterized by a functional defect in the mitochondrial protein frataxin (yeast Yfh1). It is generally agreed that frataxin is a key component of $\mathrm{Fe} / \mathrm{S}$ protein biogenesis (Stemmler et al. 2010). Cells with defective frataxin not only show a low assembly efficiency of $\mathrm{Fe} / \mathrm{S}$ proteins but also a characteristic accumulation of iron in mitochondria. Although initially this was attributed to a specific role of frataxin in mitochondrial iron storage and/or iron exit from mitochondria (Radisky et al. 1999; Cavadini et al. 2002), it turned out that this mitochondrial iron-overload phenotype is generally shared by deficiencies or diseases in other core members of the ISC assembly system (Kispal et al. 1999; Schilke et al. 1999; Lange et al. 2000; Chen et al. 2002; Rodriguez-Manzaneque et al. 2002; Biederbick et al. 2006; Wiedemann et al. 2006; Sheftel et al. 2010a; Rouault 2012) pointing to the primary role of frataxin in $\mathrm{Fe} / \mathrm{S}$ protein biogenesis. It should be noted at this point that other more recently discovered $\mathrm{Fe} / \mathrm{S}$ diseases do not show any conspicuous alterations of the cellular iron metabolism. This raises the interesting question of how these differences may be biochemically explained.

In this review, we will first summarize the mechanisms of mitochondrial $\mathrm{Fe} / \mathrm{S}$ protein biogenesis by describing in some detail the current functional knowledge of the mitochondrial ISC assembly components. Because mitochondria are essential for life owing to their role in the maturation of indispensable cytosolic and nuclear Fe/S proteins (Fig. 1), we next will explain the mechanism of how mitochondria, in concert with the components of the CIA machinery, facilitate the assembly of these proteins. We then will lay out how the assembly process affects important pathways of life such as cytosolic protein translation, nuclear genome stability, and DNA maintenance. Next, we will briefly address how an ISC assembly deficiency affects the cellular iron metabolism in both yeast and humans. Finally, we describe several Fe/S diseases in which ISC components are genetically altered. The biochemical analyses of the diseased cells both contribute to and serve as a rigorous test of our current mechanistic understanding of $\mathrm{Fe} / \mathrm{S}$ protein biogenesis.

\section{BIOGENESIS OF MITOCHONDRIAL Fe/S PROTEINS BY THE ISC ASSEMBLY MACHINERY}

The majority of functional studies of mitochondrial $\mathrm{Fe} / \mathrm{S}$ protein biogenesis have been performed in the yeast Saccharomyces cerevisiae, which has served as a simple model organism to dissect this complicated biosynthesis pathway. The fact that the basic mechanism of mitochondrial ISC assembly has been inherited in evolution from the bacterial ancestor of the organelles has been useful to transfer functional insights from studying the related bacterial ISC assembly system to the eukaryotic situation (Johnson et al. 2005; Bandyopadhyay et al. 2008a; Py and Barras 2010). More recent studies in human cells (using both cultured cell lines and patient material) have underlined the striking conservation of both the ISC components 
and the biosynthetic mechanisms from yeast to man (Sheftel et al. 2010a; Rouault 2012).

The ISC assembly machinery consists of 17 known components. Functionally, the biosynthetic process has been dissected experimentally into three major steps (Fig. 2) (Mühlenhoff et al. 2003). First, a [2Fe-2S] cluster is synthesized on the highly conserved scaffold protein Isu1, which provides both an assembly platform and a transient binding site for the nascent $\mathrm{Fe} / \mathrm{S}$ cluster. Next, the association of the Fe/S cluster on Isul is labilized by the interaction of holo-Isu1 with a dedicated Hsp70 chaperone system, fol- lowed by the transient binding of the cluster to so-called Fe/S cluster transfer proteins. The biogenesis proteins participating up to this step comprise the core ISC assembly components and are also crucially involved in the biogenesis of extramitochondrial Fe/S proteins (Fig. 2). In the third major step, the Fe/S cluster is specifically targeted to mitochondrial apoproteins and inserted into the polypeptide chains by coordination with dedicated amino acid residues. The latter reactions are supported by the specific function of ISC-targeting factors. In the following sections, we will describe the molecular

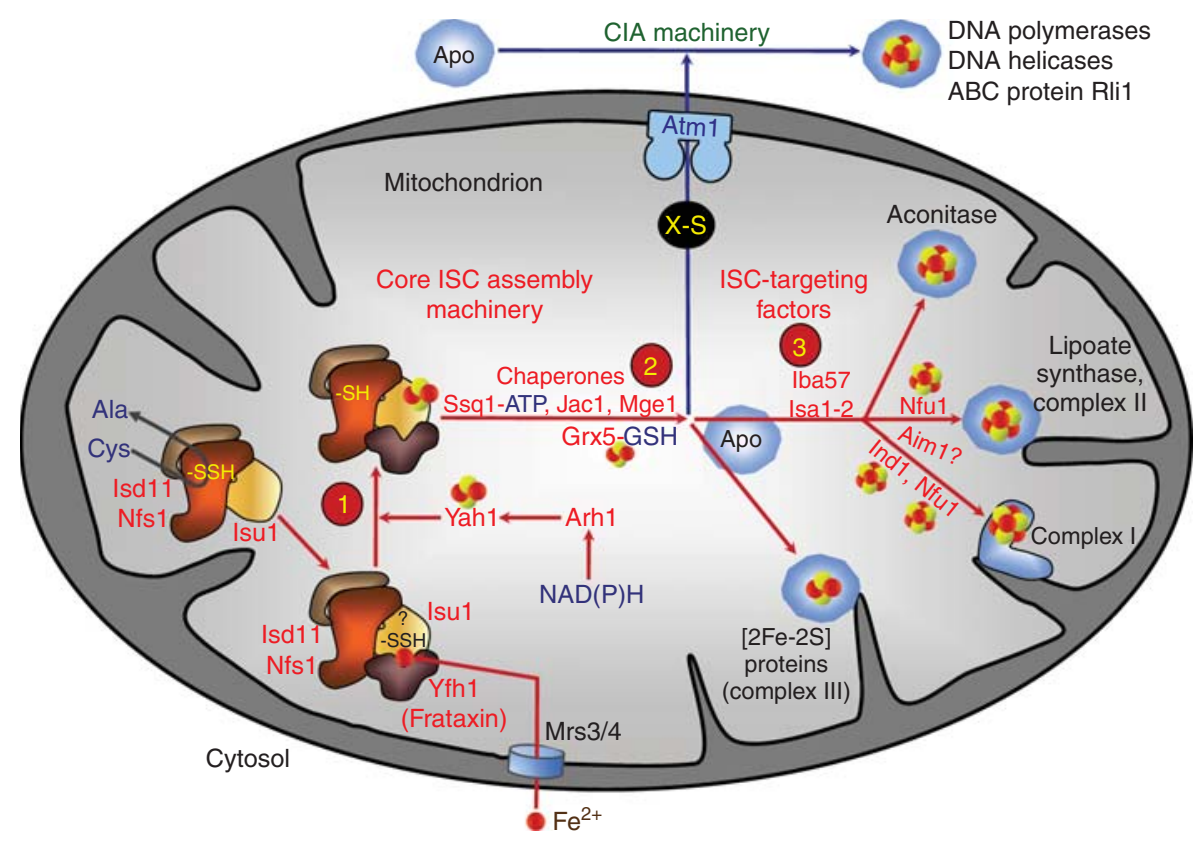

Figure 2. The three key steps of mitochondrial Fe/S protein assembly. In the first step (1), a [2Fe-2S] cluster is assembled on the Isu1 scaffold protein, which tightly interacts with the cysteine desulfurase complex Nfs1-Isd11 serving as the sulfur donor. The initially formed persulfide (-SSH) on Nfs1 by conversion of cysteine to alanine is possibly next transferred to Isu1. Fe/S cluster assembly on Isu1 then requires Yfh1 (frataxin) and the electron transfer chain consisting of the [2Fe-2S] ferredoxin Yah1 and ferredoxin reductase Arh1, which receives electrons from $\mathrm{NAD}(\mathrm{P}) \mathrm{H}$. The mitochondrial carrier proteins Mrs3-Mrs4 supply ferrous iron. In the second step (2), the $\mathrm{Fe} / \mathrm{S}$ cluster is released from Isu1, which involves the specialized Hsp70 chaperone system comprised of Ssq1, $\mathrm{Jac1}$, and Mge1. This may lead to Fe/S cluster transfer to the monothiol glutaredoxin Grx5, which binds the metallo-cofactor in a glutathione (GSH)-dependent fashion. All of these ISC components form the core ISC assembly machinery, and are required for biogenesis of all cellular $\mathrm{Fe} / \mathrm{S}$ proteins including those assembled by the CIA machinery (see Fig. 3) in the cytosol and nucleus (blue arrows). Finally, the third step (3) involves dedicated ISC-targeting factors, which transfer the cluster to specific apoproteins and assemble it into the polypeptide chains. Biogenesis of [4Fe-4S] clusters is facilitated by Isa1-Isa2 and Iba57, which may bind folate. Nful and Aim1 are essential for the specific maturation of respiratory complexes I and II, and for lipoate synthase. Complex I assembly further needs the P-loop ATPase Ind1, which, similar to Nfu1, transiently coordinates a $[4 \mathrm{Fe}-4 \mathrm{~S}]$ cluster. 
functions of the individual ISC assembly components participating in the three biogenesis steps in more detail.

$\mathrm{Fe} / \mathrm{S}$ cluster assembly on Isu1 (in yeast also on the functionally redundant Isu2) requires the cysteine desulfurase complex Nfs1-Isd11, which releases sulfur from free cysteine to form both alanine and an Nfs 1 cysteine residue-bound persulfide as an intermediate (Fig. 2) (Kispal et al. 1999; Adam et al. 2006; Biederbick et al. 2006; Wiedemann et al. 2006; Shi et al. 2009). The Nfs1 protein is related to the founding member of cysteine desulfurases, NifS, the sulfur donor for the $\mathrm{Fe} / \mathrm{S}$ clusters of the complex metalloprotein nitrogenase of nitrogen-fixing bacteria. In vivo, the Nfs1-Isd11 complex rather than Nfs1 alone is the functional entity for sulfur activation and for $\mathrm{Fe} / \mathrm{S}$ cluster synthesis on the Isu1 scaffold. To achieve the latter reaction, Nfs1Isd 11 and Isu 1 directly interact and it is thought, but not yet proven, that the persulfide is transferred from Nfs 1 to one of the three conserved cysteine residues of Isu1. After ferrous iron import via the mitochondrial carriers Mrs3-Mrs4 (human mitoferrin 1/2; Fig. 2) and iron binding to Isul the Fe/S cluster is formed by a still unknown chemical mechanism. It is generally agreed on that frataxin participates in this partial reaction of $\mathrm{Fe} / \mathrm{S}$ protein maturation. One suggestion for the molecular function of frataxin is that it functions as an iron-binding protein and delivers the metal ions to Isu1. Consistent with this idea, frataxin tightly interacts with the Nfs1Isd11-Isul complex (Gerber et al. 2003; Tsai and Barondeau 2010; Bridwell-Rabb et al. 2011; Schmucker et al. 2011; Colin et al. 2013). Whether this complex formation is stimulated by the presence of iron or not is controversial. An alternative, not necessarily mutually exclusive suggestion is that frataxin functions as a regulator of the Nfs1 desulfurase activity. Frataxin was found to be required for sulfide production by human Nfs1-Isd11, and stimulated the desulfurase activity maximally when all components of the reaction including iron were present. Frataxin therefore was proposed to act as an allosteric regulator of this initial step of Fe/S cluster formation. Further details of frataxin and the relation to Friedreich's ataxia will be discussed below. Formally, for the reduction of the persulfidic sulfur $\left(S^{0}\right)$ on $\mathrm{Nfs} 1$ (or Isu1) to sulfide $\left(\mathrm{S}^{2-}\right)$ present in $\mathrm{Fe} / \mathrm{S}$ clusters, a reduction step is needed but it is unclear how this reaction may take place. Because the $[2 \mathrm{Fe}-2 \mathrm{~S}]$ ferredoxin Yah1 ( $\mathrm{Fdx} 2$ in mammals) is necessary in vivo for $\mathrm{Fe} / \mathrm{S}$ cluster generation on Isu 1 it seems likely that Yah1, together with ferredoxin (adrenodoxin) reductase and $\mathrm{NAD}(\mathrm{P}) \mathrm{H}$, provides the needed electrons (Fig. 2) (Lange et al. 2000; Sheftel et al. 2010b). Direct functional evidence for this idea is still lacking.

The second major step of mitochondrial $\mathrm{Fe} / \mathrm{S}$ protein biogenesis involves the release of the Isul-bound $\mathrm{Fe} / \mathrm{S}$ cluster and its transient binding by $\mathrm{Fe} / \mathrm{S}$ transfer proteins (Fig. 2). The dissociation of the Fe/S cluster from Isu1 is facilitated by a dedicated Hsp70 chaperone system comprised of the Hsp70 ATPase Ssq1 (human mortalin), the DnaJ-like cochaperone Jac1 (human Hsc20), and the nucleotide exchange factor Mge1 (human GRPE-L1/2) (Schilke et al. 2006; Vickery and Cupp-Vickery 2007; Uhrigshardt et al. 2010). The molecular mechanism of the chaperones in this reaction is strikingly similar to Hsp70 chaperone function in protein folding, and has been worked out in both bacteria and yeast (Vickery and Cupp-Vickery 2007; Kampinga and Craig 2010). First, Jac1 specifically binds to Isu1 (Ciesielski et al. 2012). The complex of holo-Isul and Jacl recruits the ATPbound form of the Hsp70 (Pukszta et al. 2010). This leads to a highly specific interaction of the peptide-binding domain of Ssq1 with the conserved LPPVK loop of Isul followed by ATP hydrolysis on Ssq1. The conformational change of Isul during complex formation is thought to labilize Fe/S cluster binding to Isul thus facilitating its dissociation. The constituents of the Ssq1-ADP-apo-Isu1 complex are then recycled by ADP-ATP exchange on Ssq1, a step facilitated by the nucleotide exchange factor Mge1. Dissociation enables Isu1 and Ssq1 to undergo the next round of Fe/S cluster synthesis and transfer.

The released Fe/S cluster may then be transferred to the mitochondrial monothiol glutaredoxin Grx5 or directly to apoproteins (Chandramouli and Johnson 2006; Bonomi et al. 2008). Grx5 possibly serves as an Fe/S cluster 
transfer protein by transiently coordinating the Isul-derived [2Fe-2S] cluster between two protein subunits and two protein-bound glutathione molecules (Bandyopadhyay et al. 2008b; Shakamuri et al. 2012). Recently, Grx5 was shown to specifically associate with Ssq1 at a site different from the chaperone peptide-binding pocket (Uzarska et al. 2013). The simultaneous binding of holo-Isul and apo-Grx5 to Ssq1 potentially increases the efficiency of $\mathrm{Fe} / \mathrm{S}$ cluster transfer. However, at least to some extent, a direct delivery of the $\mathrm{Fe} / \mathrm{S}$ cluster to target apoproteins seems possible, because Grx5, unlike most of the ISC proteins discussed so far, is not essential for viability of yeast cells. Nevertheless, deletion of the yeast GRX5 gene leads to a severe $\mathrm{Fe} / \mathrm{S}$ protein assembly defect both inside and outside mitochondria and is associated with a pronounced sensitivity to oxidative stress, possibly as a result of the iron accumulation in mitochondria (see below). In both humans and zebrafish, GLRX5 is essential for life (Wingert et al. 2005; Camaschella et al. 2007; Ye et al. 2010). In humans, a mutation leading to decreased amounts of GLRX5 causes a severe iron-storage disease with a characteristic cellular $\mathrm{Fe} / \mathrm{S}$ protein and heme synthesis defect as well as with an iron accumulation in mitochondria as indicated by the occurrence of ringed sideroblasts (Cazzola and Invernizzi 2011).

The third major step of mitochondrial Fe/S protein biogenesis involves the delivery of the $\mathrm{Fe} / \mathrm{S}$ cluster to specific target apoproteins and the dedicated integration of the cluster into the polypeptide chain by coordination of its iron ions with specific amino acid ligands. For the formation of [2Fe-2S] proteins, no other factors have been identified in addition to the mentioned members of the core ISC assembly machinery (Fig. 2). For all mitochondrial [4Fe-4S] proteins, on the other hand, cofactor insertion must be preceded or accompanied by conversion of the $[2 \mathrm{Fe}-2 \mathrm{~S}]$ cluster that has been synthesized on Isul and transferred by Grx5. This reaction is accomplished by the A-type ISC proteins Isa1 and Isa2 (human ISCA1 and ISCA2) and the tetrahydrofolate-binding protein Iba57 (Mühlenhoff et al. 2007, 2011; Gelling et al. 2008; Song et al. 2009; Long et al. 2011; Sheftel et al. 2012). The three proteins functionally interact with each other, and deletion of the individual genes elicits highly similar phenotypes indicating that they cooperate in the same reaction (Gelling et al. 2008; Waller et al. 2010; Mühlenhoff et al. 2011; Sheftel et al. 2012). How the three proteins mechanistically help in generating the $[4 \mathrm{Fe}-4 \mathrm{~S}]$ cluster is currently unresolved. This is mainly owing to the fact that it is still unclear what the physiological meaning of different forms of iron bound to different members of the Isa protein family may be. The yeast Isa 1 and Isa 2 proteins were shown to bind iron in vitro and in vivo, even under conditions when $\mathrm{Fe} / \mathrm{S}$ cluster synthesis is blocked (Lu et al. 2010; Mühlenhoff et al. 2011). However, by which mechanism the iron-binding Isa proteins may assist in the conversion of the Isul-generated [2Fe-2S] cluster into a [4Fe-4S] moiety remains unclear. In bacteria, the related A-type ISC proteins IscA, ErpA, and SufA were shown to bind either iron or a [2Fe-2S] cluster (see, e.g., Gupta et al. 2009; Py and Barras 2010; Wang et al. 2010; Mapolelo et al. 2013). However, the physiological relevance of the two different bound iron cofactors remains to be resolved.

The final step of specific insertion of the [4Fe-4S] cluster into the polypeptide chains of various apoproteins depends on a number of ISC assembly factors that show target protein specificity (Fig. 2). Unlike the core ISC assembly components, these factors are required for maturation of subsets of Fe/S proteins, yet are dispensable for others. Some of the factors appear to show overlapping substrate specificity explaining why deletion of their genes is associated with a comparatively mild phenotype. For instance, complex I maturation involves the P-loop NTPase Ind1, and to date, no other targets of Ind 1 are known. Ind 1 is a close homolog of the CIA proteins Cfd1 and Nbp35 discussed below, and similarly to these proteins, Ind 1 transiently binds $[4 \mathrm{Fe}-4 \mathrm{~S}]$ clusters and transfers them to the $\mathrm{Fe} / \mathrm{S}$ subunits of complex I (Bych et al. 2008; Sheftel et al. 2009). The ISC assembly protein Nful shows a broader target specificity including complexes I and II of the respiratory chain and lipoate synthase, whereas aconitase does not depend on this maturation factor (Cameron 
et al. 2011; Navarro-Sastre et al. 2011). Like Ind1, Nful also binds a $[4 \mathrm{Fe}-4 \mathrm{~S}]$ cluster (Tong et al. 2003), and may transfer it to its targets (NavarroSastre et al. 2011). Interestingly, the target protein specificity of Nful was initially revealed from the biochemical phenotype of patients with genetic mutations in this gene (Cameron et al. 2011; Navarro-Sastre et al. 2011). In addition to defects in complexes I and II, affected patients show severe deficits in lipoate-containing proteins such as pyruvate dehydrogenase, 2-ketoglutarate dehydrogenase, and the $\mathrm{H}$ protein of glycine cleavage system. This suggested that human NFU1 acts as a specific targeting factor for these mitochondrial [4Fe-4S] proteins. Based on these results, the Nful substrate specificity was confirmed in yeast indicating that its function is conserved in eukaryotes $(\mathrm{Na}-$ varro-Sastre et al. 2011). The role of Ind 1 and Nful as late-acting ISC proteins also becomes obvious from the dependence of the assembly of their own transiently bound $\mathrm{Fe} / \mathrm{S}$ cluster on earlier acting ISC assembly proteins such as Nfs1, Isu1, and Ssq1.

A similar role as for NFU1 was suggested for human BOLA3 (yeast relative Aim1) (Cameron et al. 2011). This protein belongs to a family of typically three members, two of which are located in mitochondria (BOLA1 and BOLA3) and another one representing a cytosolic protein (yeast Fra2 and human BOLA2) (Kumanovics et al. 2008; Li and Outten 2012). Patients with mutations in BOLA3 show a similar biochemical phenotype as NFU1-deficient individuals. The molecular function of the protein and its potential cooperation with the other late-acting ISC factors remains to be resolved.

\section{ASSEMBLY OF CYTOSOLIC AND \\ NUCLEAR Fe/S PROTEINS INVOLVES \\ MITOCHONDRIA AND THE CIA MACHINERY}

As mentioned above, the cytosol and nucleus of eukaryotic cells contain many $\mathrm{Fe} / \mathrm{S}$ proteins with utmost importance for cell survival. It has been recognized as early as in 1999 that their maturation strictly depends on the function of members of the mitochondrial ISC assembly machinery (Figs. 1 and 2) (Kispal et al. 1999). More recent studies have indicated that only the members of the core ISC assembly machinery are assisting biogenesis steps 1 and 2, but not the ISC-targeting factors that facilitate step 3 only (cf. Fig. 2). In particular, the cysteine desulfurase Nfs1 and the scaffold Isu1 have been shown to be required inside mitochondria for $\mathrm{Fe} / \mathrm{S}$ protein assembly in the cytosol and nucleus (Gerber et al. 2004; Mühlenhoff et al. 2004; Biederbick et al. 2006). Hence, mitochondria seem to produce the sulfur moiety for cytosolic $\mathrm{Fe} / \mathrm{S}$ clusters. Why all other members of the ISC core machinery are required as well, and what the chemical nature of the activated sulfur species may be, has remained unclear over many years of research. Numerous studies in yeast, man, mice and zebrafish have shown that deletion of the $\mathrm{ABC}$ transporter Atm1 (human $\mathrm{ABCB} 7)$ of the mitochondrial inner membrane leads to a functional deficiency in cytosolic and nuclear $\mathrm{Fe} / \mathrm{S}$ proteins, whereas mitochondrial $\mathrm{Fe} / \mathrm{S}$ proteins are largely unaffected (Kispal et al. 1999; Pondarre et al. 2006; Miao et al. 2009). Hence, it is proposed that Atm 1 facilitates the export of the sulfur-containing compound (X-S in Fig. 2) from the mitochondrial matrix to the cytosol for integration into extramitochondrial $\mathrm{Fe} / \mathrm{S}$ proteins. Additionally, depletion of the sulfhydryl oxidase Erv1 of the intermembrane space and of the tripeptide glutathione (GSH) leads to a similar phenotype as deletion of Atm 1, namely, cytosolic-nuclear Fe/S protein defects, yet no severe effects on mitochondrial $\mathrm{Fe} / \mathrm{S}$ proteins. Therefore, these three components have been coined as "ISC export machinery" (Lill and Mühlenhoff 2005).

Research of the past 10 years has identified eight cytosolic proteins with essential functions in the biogenesis of cytosolic and nuclear Fe/S proteins (Fig. 3). Together, they comprise the CIA machinery (Sharma et al. 2010). The proteins can be attributed to various partial reactions that are formally similar to those performed by the mitochondrial ISC machinery (Netz et al. 2007, 2010, 2012a). First, a [4Fe$4 \mathrm{~S}$ ] cluster is transiently assembled on the Ploop NTPases Cfd1 and Nbp35, which serve as a scaffold. This step requires the core mitochon- 


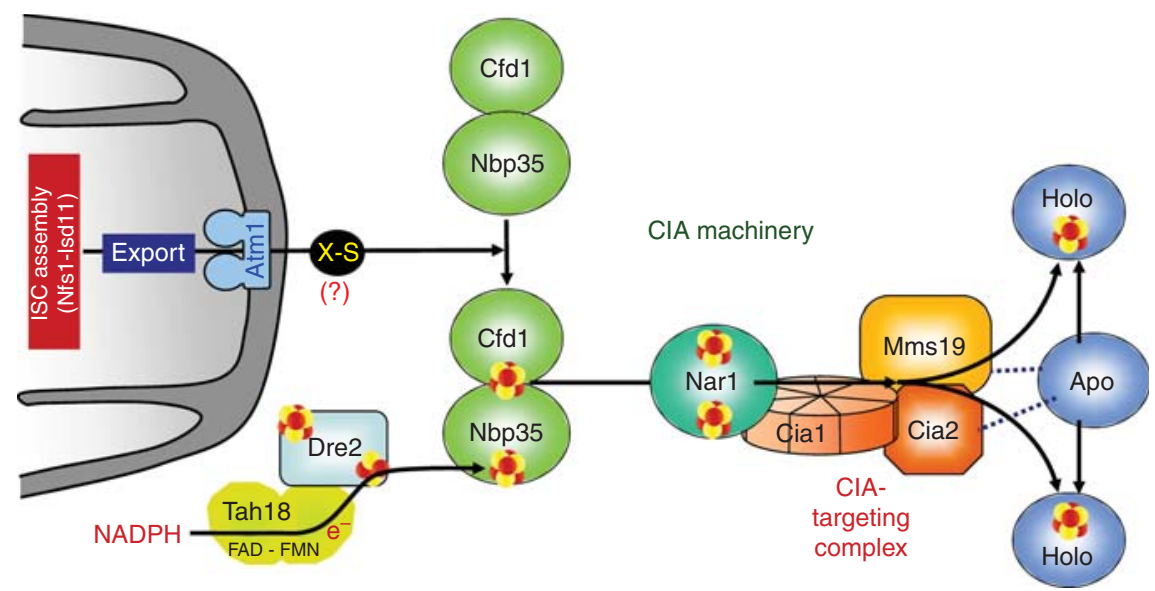

Figure 3. A model for assembly of cytosolic and nuclear Fe/S proteins. The CIA machinery comprises eight known proteins. In a first step, a bridging [ $4 \mathrm{Fe}-4 \mathrm{~S}$ ] cluster is assembled on the Cfd $1-\mathrm{Nbp} 35$ scaffold complex. This reaction requires a sulfur source $(\mathrm{X}-\mathrm{S})$ generated by the mitochondrial ISC assembly machinery and exported by the mitochondrial ABC transporter Atm1 (human ABCB7). Generation of the functionally essential amino-terminal $\mathrm{Fe} / \mathrm{S}$ cluster of Nbp35 (bottom) depends on the flavoprotein Tah18 and the Fe/S protein Dre2, which serve as an NADPH-dependent electron transfer chain. In the second step, the bridging Fe/S cluster is released from Cfd1$\mathrm{Nbp35}$, a reaction mediated by Nar1 and the CIA-targeting complex Cia1-Cia2-Mms19. The latter two proteins interact with target (apo)proteins and assure specific $\mathrm{Fe} / \mathrm{S}$ cluster insertion. Biogenesis further requires, at an unknown step, the cytosolic multidomain monothiol glutaredoxins Grx3-Grx4 (human PICOT), which bind a glutathione-coordinated, bridging [2Fe-2S] cluster (not shown). These proteins also play a role in intracellular iron trafficking.

drial ISC assembly machinery, including Nfs1, as a sulfur donor (see Fig. 2) (Nakai et al. 2001; Mühlenhoff et al. 2004; Biederbick et al. 2006). Cfd1-Nbp35 form a heterotetramer and bind the $[4 \mathrm{Fe}-4 \mathrm{~S}]$ cluster in a bridging manner on two conserved cysteine residues of two monomers. Mutation of the Walker motif of Cfd 1 and Nbp35 showed that it is essential for function of these proteins (Sharma et al. 2010; Netz et al. 2012a). It is therefore generally assumed that NTP hydrolysis is needed for Fe/S cluster assembly, but hitherto neither nucleotide binding nor hydrolysis has been proven experimentally. Therefore, the precise role of the nucleotidebinding motif for Cfd1-Nbp35 function remains to be determined. In addition to the transient $\mathrm{Fe} / \mathrm{S}$ cluster, Nbp35 contains another [4Fe$4 \mathrm{~S}$ ] cluster at its amino terminus, which is stably bound and essential for function. Its assembly depends on the electron transfer chain from NADPH as an electron source, to the flavin-containing oxidoreductase Tah18, and, finally, to the Fe/S protein Dre2 (Zhang et al. 2008; Netz et al.
2010; Banci et al. 2013). What the precise role of reduction in this early step of CIA function may be is unclear. One possibility is the reduction of the sulfur moiety exported from mitochondria to sulfide, but other options are equally likely.

The transiently bound, bridging [4Fe- $4 \mathrm{~S}]$ cluster assembled on Cfd1-Nbp35 is then transferred to apoproteins. This reaction is mechanistically poorly understood. However, it is known that the CIA protein Nar1 interacts with Nbp35 and therefore may be involved in $\mathrm{Fe} / \mathrm{S}$ cluster mobilization (Balk et al. 2004; Song and Lee 2008). Nar1 shows similarity to iron-only hydrogenases and binds two [4Fe- $4 \mathrm{~S}]$ clusters, which are assembled with the help of Cfd1Nbp35 (Urzica et al. 2009). Hence, Nar1 is both a target and a component of the cellular $\mathrm{Fe} / \mathrm{S}$ protein biogenesis machinery, and possibly is required for its own maturation (Balk et al. 2004). Because later-acting CIA factors (see below) are dispensable for the assembly of the two $\mathrm{Nar} 1 \mathrm{Fe} / \mathrm{S}$ clusters, the protein may act as a mediator between early and late steps of the CIA 
biogenesis process (Fig. 3). The recently identified CIA components Cia1, Cia2, and Mms19 form the so-called CIA-targeting complex, as these proteins appear to mediate both Fe/S cluster transfer and target-specific cluster insertion into the various polypeptide chains (Fig. 3) (Srinivasan et al. 2007; Weerapana et al. 2010; Gari et al. 2012; Stehling et al. 2012). These reactions involve the direct physical interaction of the CIA-targeting complex proteins with the target $\mathrm{Fe} / \mathrm{S}$ proteins, presumably their apoforms. This became most evident from affinity pull-down experiments in human cells where the various CIA-targeting factors interacted with a large number of cytosolic and nuclear Fe/S proteins (Stehling et al. 2012). This protein list includes DNA polymerases and primases, ATP-dependent DNA helicases, DNA glycosylases, and the $\mathrm{ABC}$ protein $\mathrm{ABCE} 1$. In yeast, the interactions between CIA components and Fe/S target proteins seem to be weaker or less stable, and only a few such interactions have been identified including the binding of Fe/S helicase Rad3 to Mms19 and of the helicase-nuclease Dna2 to Cia2 (Stehling et al. 2012). The precise molecular function of the late-acting CIA components remains to be determined.

In addition to the mentioned proteins, the cytosolic monothiol glutaredoxins Grx3-Grx4 (human PICOT) were shown to be crucial for cytosolic and nuclear $\mathrm{Fe} / \mathrm{S}$ protein biogenesis (Mühlenhoff et al. 2010). Because these proteins are involved in intracellular iron trafficking and iron uptake regulation, they seem to play a more general function and hence are no typical CIA proteins. For instance, these glutaredoxins are also involved in the maturation of di-iron proteins such as ribonucleotide reductase or in heme biosynthesis in erythroid cells (Mühlenhoff et al. 2010; Zhang et al. 2011; Haunhorst et al. 2013). Failure of the glutaredoxins to participate in these processes or in $\mathrm{Fe} / \mathrm{S}$ protein biogenesis explains the drastic effect on the viability of cells lacking both proteins. How the glutaredoxins mechanistically fulfill their ironrelated function is currently unknown.

Overall, the process of cellular Fe/S protein biogenesis is surprisingly complex with some 30 components being directly involved. Howev- er, it seems likely that more components with a function in this essential process will be discovered in the future.

\section{THE MITOCHONDRIAL CONTRIBUTION TO EXTRAMITOCHONDRIAL Fe/S PROTEIN MATURATION EXPLAINS THE INDISPENSABLE CHARACTER OF THE ORGANELLES}

More than half of the known ISC and almost all CIA components are essential for the viability of yeast cells (Lill and Mühlenhoff 2005, 2008). In humans, even ISC genes that can be knocked out in yeast without major consequences are essential for life (e.g., NFU1; for details see below). Hence, their contribution to cellular Fe/S protein biogenesis renders mitochondria essential for life. This essentiality sharply contrasts with the importance of other mitochondrial functions such as ATP synthesis, citric acid cycle, and fatty acid oxidation that can be deleted without the loss of cell viability, at least in yeast. This organism can survive without respiratory competent mitochondria when cultivated on media containing fermentable carbon sources such as glucose. Strikingly, a nonessential function of mitochondrial respiration and ATP synthesis is evident also for human cells, at least under certain conditions. For instance, cultured human cells lacking their mitochondrial DNA ( $\rho^{0}$ cells) are viable despite the absence of oxidative phosphorylation, as long as they are supplied with high glucose, which is used for ATP production by glycolysis. These points clearly indicate that respiration and other classical mitochondrial functions are not primarily responsible for the essential character of mitochondria in eukaryotes. Rather, the involvement in the maturation of cellular $\mathrm{Fe} / \mathrm{S}$ proteins satisfactorily explains why mitochondria are needed for life.

This conclusion has received impressive biological support from the thorough genetic analysis of a number of diverse species that originally were thought to lack mitochondria altogether, and hence were called amitochondriates (for review see Molik and Lill 2012, and citations therein). These species contain either hydrogenosomes or mitosomes, both of which are 
double membrane-bounded organelles that are evolutionarily related to classical mitochondria. They have evolved from mitochondria-containing species by successive loss of mitochondrial genes and mitochondria-typical functions such as respiration, citric acid cycle, and heme synthesis (Embley and Martin 2006; van der Giezen 2009; Muller et al. 2012). As a consequence, mitosomes present in, for example, microsporidia, diplomonads, and amoebozoa, have lost virtually all classical functions of mitochondria, with the notable exception of $\mathrm{Fe} / \mathrm{S}$ protein biogenesis (Tovar et al. 2003; Goldberg et al. 2008). Strikingly, mitosomes do not contain any Fe/S proteins, which would explain the maintenance of the ISC assembly machinery. The only known mitosomal $\mathrm{Fe} / \mathrm{S}$ protein is the [2Fe-2S] ferredoxin Yah1, which itself is an ISC component involved in $\mathrm{Fe} / \mathrm{S}$ protein maturation. Hence, it can be speculated that the remnant function of mitosomes and its "leftover" ISC system lies in the maturation of extramitochondrial $\mathrm{Fe} / \mathrm{S}$ proteins.

Which extramitochondrial $\mathrm{Fe} / \mathrm{S}$ proteins may then explain the essentiality of mitochondrial $\mathrm{Fe} / \mathrm{S}$ protein biogenesis? The first known example of an essential extramitochondrial $\mathrm{Fe} / \mathrm{S}$ protein was the ABC protein Rli1, a component involved in ribosome function and assembly (Kispal et al. 2005; Yarunin et al. 2005; Becker et al. 2012). Other recently identified essential $\mathrm{Fe} / \mathrm{S}$ proteins include components involved in nucleotide excision repair $(\operatorname{Rad} 3$, human XPD), RNA primer synthesis during DNA replication (Pri2) (Rudolf et al. 2006; Klinge et al. 2007), DNA replication (DNA polymerases) (Netz et al. 2012b), and telomere length variation (RTEL1) (Gari et al. 2012). Recently, it was experimentally proven for some of these proteins that their maturation requires both the mitochondrial ISC and the cytosolic CIA components, and that assembly defects lead to increased sensitivity to DNA damage agents such as UV light and mutagenic chemicals (Gari et al. 2012; Stehling et al. 2012). These findings imply that mitochondria, via their function in $\mathrm{Fe} / \mathrm{S}$ protein maturation, play a direct role in fundamental processes of life such as nuclear DNA maintenance, gene expression, and genome stability.

\section{MITOCHONDRIAL Fe/S PROTEIN BIOGENESIS IS A KEY REGULATOR OF CELLULAR IRON HOMEOSTASIS}

It has long been recognized that $\mathrm{Fe} / \mathrm{S}$ protein biogenesis performs a regulatory role in cellular iron metabolism. This makes physiological sense, as the supply of the metal is directly controlled by an iron-consuming process. Nevertheless, this regulatory mechanism is remarkable as heme synthesis does not directly impact on the adjustment of iron supply, at least not in nonerythroid cells. In particular, it is the mitochondrial ISC system that plays a key role in cellular iron homeostasis. Functional depletion of the core components of the mitochondrial ISC assembly and export systems is associated with increased cellular iron uptake and usually with an iron overload of mitochondria. This phenomenon is similar in yeast and human cells, even though the underlying regulatory mechanisms differ substantially. In yeast, the iron regulatory function is mostly exerted by transcriptional activation of the Aft1-Aft2-transcription factor-dependent iron regulon genes, whereas other fungi use repressor systems (for comprehensive recent reviews, see Schrettl and Haas 2011; Lill et al. 2012; Philpott et al. 2012). In human cells, the major impact on cellular iron supply and distribution within the cell is mediated by the two iron regulatory proteins (IRP) 1 and 2 via complex posttranscriptional mechanisms (for comprehensive recent reviews, see Anderson et al. 2012; Thompson and Bruick 2012). Here, we will only briefly summarize which events may lead to cellular iron uptake and mitochondrial iron accumulation when (mitochondrial) Fe/S protein biogenesis is functionally impaired. Many details of this regulatory pathway are still poorly defined at the molecular level.

In yeast, depletion of any member of the core mitochondrial ISC assembly machinery or of the ISC export system including the ABC transporter Atm 1 leads to activation of the ironsensing transcription factors Aft1-Aft2 and an induction of genes of the iron regulon (Figs. 1 and 2). This includes some 30 genes that are involved in cellular iron acquisition and proper 
intracellular distribution of the metal to various compartments including mitochondria and vacuoles. What is the molecular basis for the role of the mitochondrial ISC system in iron regulation? Likely, the core ISC machinery produces and Atm1 exports a sensor molecule to the cytosol, which is then used by Aft1-Aft2 to interpret the mitochondrial iron status. It is reasonable to believe that the molecule X-S used for $\mathrm{Fe} / \mathrm{S}$ protein maturation by the CIA machinery and the iron sensor are identical or at least chemically related. The Aft transcription factors interact with the monothiol glutaredoxins Grx3-Grx4 mentioned above and the BolA protein Fra2 (Mühlenhoff et al. 2010; Li and Outten 2012). Deletion of Grx3-Grx4 leads to strong activation of the Aft iron regulon and cellular iron uptake. The iron accumulates in the cytosol and not in mitochondria, thus differing from the situation with defects in ISC proteins where iron levels strongly increase in mitochondria (see above). The glutaredoxins bind a $[2 \mathrm{Fe}-2 \mathrm{~S}]$ cluster and it may be hypothesized that this cluster is the molecule sensed by $\mathrm{Aft} 1-\mathrm{Aft} 2$, but in vivo evidence for this hypothesis is lacking.

In human cells, intracellular iron regulation is accomplished by IRP1 and IRP2. IRP1 is a cytosolic $\mathrm{Fe} / \mathrm{S}$ protein with aconitase activity, yet in its apoform it can bind to iron-responsive elements (IREs) of messenger RNAs (mRNAs), which encode proteins involved in iron trafficking (transferrin receptor and ferroportin), storage (ferritin), and utilization (aconitase and eALAS), thereby regulating the efficiency of translation or the mRNA stability (Anderson et al. 2012; Thompson and Bruick 2012). The equilibrium between the apo- and holoforms of IRP1 is shifted by Fe/S cluster assembly, which depends on both the mitochondrial ISC systems and the CIA machinery, which uses the mitochondria-exported molecule X-S for Fe/S cluster synthesis. Thus, unlike in yeast, depletion of both ISC and CIA components in human cells affects cellular iron regulation via IRP1. Strikingly and in similarity to the situation in yeast, iron accumulates in mitochondria on defects in the ISC systems. It is clear from these observations that both yeast and mammals regulate cel- lular iron uptake and supply to the mitochondrial matrix by the efficiency of mitochondria to generate $\mathrm{Fe} / \mathrm{S}$ clusters.

\section{DIFFERENT BIOCHEMICAL PHENOTYPES OF MITOCHONDRIAL Fe/S DISEASES PROVIDE INSIGHTS INTO THE MECHANISM OF Fe/S PROTEIN ASSEMBLY}

Over the past decade, a number of disorders with diverse clinical phenotypes have been reported as a consequence of genetic defects in mitochondrial ISC components (Fig. 4) (Sheftel et al. 2010a; Rouault 2012). Many of these diseases are fatal, sometimes in early childhood, which is not surprising based on the essential character of $\mathrm{Fe} / \mathrm{S}$ protein biogenesis. Although it is still difficult to explain the overall clinical phenotypes, it seems possible to reconcile the biochemical observations made in patient material with the mechanistic studies performed in tissue culture using RNAi-depletion technology. Hence, the disease phenotypes are a critical test of the molecular mechanism worked out for ISC assembly and can be used to extend the model for this process.

The founding member of Fe/S diseases is the neurodegenerative disorder Friedreich's ataxia, in which the early-acting ISC protein frataxin is functionally deficient, either by a more than $70 \%$ decrease in protein levels as a result of decreased transcription or by point mutations (Schmucker and Puccio 2010; Stemmler et al. 2010). This functional impairment is associated with decreased activities of respiratory complexes I-III and of mitochondrial aconitase. Moreover, frataxin-deficient cells show a defect in cytosolic IRP1 maturation and a mitochondrial iron accumulation. These biochemical phenotypes are well explained by the crucial function of frataxin as a core member of the ISC machinery (Figs. 2 and 4). It has been noted for both yeast and human cells that frataxin-deficient cells show increased sensitivity to nuclear DNA damage (Karthikeyan et al. 2002; Thierbach et al. 2010). This effect has now been explained as a general consequence of ISC (and CIA) protein defects, which hamper the assembly of critical $\mathrm{Fe} / \mathrm{S}$ components of DNA metabolism such as 


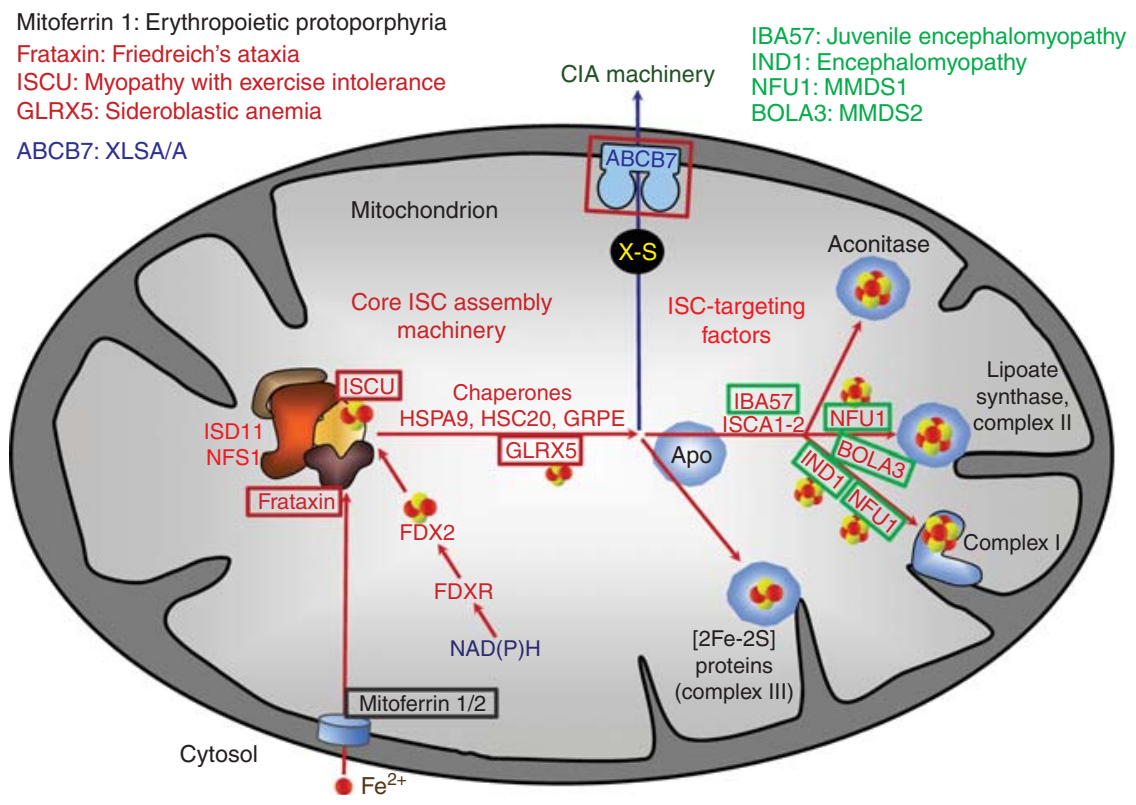

Figure 4. Diseases associated with the assembly of mitochondrial and cytosolic Fe/S proteins. The model is a simplified version of Fig. 2 showing the human ISC protein names. The boxes highlight ISC proteins, which are mutated in two different kinds of $\mathrm{Fe} / \mathrm{S}$ diseases. Red boxes indicate $\mathrm{Fe} / \mathrm{S}$ diseases that are associated with a mitochondrial iron accumulation, whereas mutations in ISC proteins indicated by green boxes do not affect the iron metabolism. In addition, the model depicts a mitochondrial iron import disorder associated with a mutation in the inner membrane carrier mitoferrin 1 (gray box). XLSA/A, X-linked sideroblastic anemia and cerebellar ataxia; MMDS, multiple mitochondrial dysfunction syndrome.

replicative DNA polymerases and numerous DNA helicases involved in DNA repair (Gari et al. 2012; Stehling et al. 2012).

A splice mutation in the mitochondrial glutaredoxin GLRX5 drastically decreases its protein level, and causes a clinical phenotype that is rather different from Friedreich's ataxia. The GLRX5 mutation most severely affects erythroblasts causing a sideroblastic (microcytic) anemia characterized by mitochondrial iron overload (Camaschella et al. 2007). The erythroblast cell-type specificity was explained by the unique combination of the IRP targets ALAS2 (IRP-repressible) and ferroportin $1 \mathrm{~b}$ (non-IRP-repressible) (Ye et al. 2010). A third example with a mutation in a member of the core ISC assembly machinery is the muscle-specific splicing defect in the scaffold protein ISCU that causes a myopathy with exercise tolerance and lactic acidosis (Mochel et al. 2008; Olsson et al. 2008; Crooks et al. 2012; Nordin et al. 2012). Biochemically, this defect is associated with cellular Fe/S protein deficiencies and cellular iron accumulation as a result of an altered iron homeostasis. Despite striking differences in the clinical appearance, all three diseases show common biochemical alterations, which are characterized by a complex defect in mitochondrial and cytosolic $\mathrm{Fe} / \mathrm{S}$ proteins (including those carrying a [2Fe-2S] cluster) and an iron accumulation. These phenotypes are typical for early-acting ISC components and hence support the current mechanistic model of $\mathrm{Fe} / \mathrm{S}$ protein biogenesis.

Recently, several other pathogenic mutations affecting four mitochondrial late-acting ISC proteins were reported. Mutations in the P-loop NTPase IND1 specifically affect complex I activity and cause a disease phenotype that is typical for complex I defects (Sheftel et al. 2009; Calvo et al. 2010). Because IND1 can bind a [4Fe-4S] cluster, it has been suggested that IND1 may transiently bind the cluster synthe- 
sized on Isu1 before inserting it into the complex I Fe/S subunits (Bych et al. 2008). Mutations in the $[4 \mathrm{Fe}-4 \mathrm{~S}]$ protein NFU1 are associated with defects in respiratory complexes I and II, and, most strikingly, lipoate synthase (Cameron et al. 2011; Navarro-Sastre et al. 2011). The latter $\mathrm{Fe} / \mathrm{S}$ protein produces lipoic acid for the four mitochondrial enzymes pyruvate dehydrogenase, $\alpha$-ketoglutarate dehydrogenase, branchedchain ketoacid dehydrogenase (BCKDH), and the $\mathrm{H}$ protein of the glycine cleavage system (H-GCS). Patients with NFU1 mutations present with respiratory chain defects, hyperglycinemia, and low pyruvate dehydrogenase complex activities (Cameron et al. 2011; Navarro-Sastre et al. 2011). Strikingly, the [4Fe$4 \mathrm{~S}$ ] protein aconitase was not affected in NFU1 patients suggesting a target-specific function of NFU1. A similar pattern of $\mathrm{Fe} / \mathrm{S}$ protein deficiencies is seen for mutations in BOLA3 (Cameron et al. 2011) indicating a characteristic target specificity for these two ISC assembly proteins. A fourth $\mathrm{Fe} / \mathrm{S}$ disease case involving a point mutation in the late-acting ISC protein IBA57 affects both the activity and stability of the protein, and causes defects in mitochondrial [4Fe-4S] proteins including respiratory complexes I and II, aconitase, and lipoic acid synthase, whereas respiratory complex III was normal (Gelling et al. 2008; Ajit Bolar et al. 2013). Thus, the biochemical profiles of IBA57, NFU1, and BOLA3 patients substantially overlap, yet characteristically differ in the mitochondrial aconitase activity, which was normal in NFU1- and BOLA3-deficient individuals. These studies, together with mechanistic studies in yeast, provide the basis for the working model (Figs. 2 and 4) proposing that IBA57, together with ISCA1-ISCA2, assists the generation of all mitochondrial [4Fe-4S] proteins, whereas IND1, NFU1, and BOLA3 serve as more specific ISC-targeting factors.

Notably, for all four disease cases of late-acting ISC proteins, no major effects on the cellular or mitochondrial iron metabolism have been reported, which supports their late mechanistic action in the ISC assembly process (Fig. 4). Likewise, the diseased state did not show any impairment of cytosolic Fe/S protein maturation. This feature distinguishes these cases from mutations in frataxin, GLRX5, and ISCU, which show, in addition to general mitochondrial [2Fe-2S] and [4Fe-4S] protein defects, a strong impairment in cytosolic Fe/S protein maturation and a severe cellular iron accumulation as a consequence of diminished IRP1 maturation and hence activation of its IRE binding. All of these phenotypes, with the notable exception of mitochondrial $\mathrm{Fe} / \mathrm{S}$ protein defects, are observed for mutations in the ABC transporter ABCB7 (Fig. 4), which cause X-linked sideroblastic anemia and cerebellar ataxia (XLSA/A) (Bekri et al. 2000; Cazzola and Invernizzi 2011). Collectively, the presence or absence of effects on cytosolic Fe/S proteins and on cellular iron metabolism may readily allow clinicians to distinguish the two groups of mitochondrial $\mathrm{Fe} / \mathrm{S}$ diseases in which either core ISC assembly and export members or ISC-targeting factors, respectively, are functionally impaired.

\section{CONCLUSIONS AND OUTLOOK}

The assembly of mitochondrial, cytosolic, and nuclear $\mathrm{Fe} / \mathrm{S}$ proteins has turned out to be a surprisingly complex biosynthetic process, despite the chemically simple nature of the Fe/S cofactor. The central contribution of mitochondria to cellular $\mathrm{Fe} / \mathrm{S}$ protein maturation makes these organelles indispensable for life, even under situations when other more classical processes of mitochondria can be bypassed. Because biogenesis targets $\mathrm{Fe} / \mathrm{S}$ proteins participating in many diverse cellular pathways, numerous downstream biochemical processes are affected when Fe/S protein assembly is impaired. Examples include, in addition to various steps of amino acid and nucleotide anabolism and catabolism, cellular iron homeostasis (which is regulated by mitochondrial Fe/S protein assembly), cytosolic protein translation, DNA synthesis and repair, as well as the complex issue of genome integrity. Undoubtedly, Fe/S protein biogenesis is one of the most basic biosynthetic processes of life.

Future studies on this important cellular process will be dedicated to the better biochemical definition of the function of individual biogenesis components. This will be supported by 
insights into the 3D structures of ISC and CIA components, knowledge about the dynamics of the protein interactions underlying the various biogenesis steps, and the elucidation of the regulation of the process. Even though it is safe to state that most biogenesis components have been identified to date, there are likely a few more of these components to be discovered and functionally characterized in the near future.

\section{ACKNOWLEDGMENTS}

We thank our group for fruitful discussions. Research is generously supported by grants from Deutsche Forschungsgemeinschaft (SFB 593, SFB-TR1, SFB 987, and GRK 1216), von Behring-Röntgen Stiftung, LOEWE program of state Hessen, and Max-Planck Gesellschaft.

\section{REFERENCES}

Adam AC, Bornhövd C, Prokisch H, Neupert W, Hell K. 2006. The Nfs1 interacting protein Isd 11 has an essential role in $\mathrm{Fe} / \mathrm{S}$ cluster biogenesis in mitochondria. $E M B O J$ 25: $174-183$.

Ajit Bolar N, Vanlander AV, Wilbrecht C, Van der Aa N, Smet J, De Paepe B, Vandeweyer G, Kooy F, Eyskens F, De Latter E, et al. 2013. Mutation of the iron-sulfur cluster assembly gene IBA57 causes severe myopathy and encephalopathy. Hum Mol Genet 22: 2590-2602.

Alfonzo JD, Lukes J. 2011. Assembling Fe/S-clusters and modifying tRNAs: Ancient co-factors meet ancient adaptors. Trends Parasitol 27: 235-238.

Anderson CP, Shen M, Eisenstein RS, Leibold EA. 2012. Mammalian iron metabolism and its control by iron regulatory proteins. Biochim Biophys Acta 1823: 1468-1483.

Balk J, Pilon M. 2011. Ancient and essential: The assembly of iron-sulfurclusters in plants. Trends Plant Sci 16:218-226.

Balk J, Pierik AJ, Aguilar Netz D, Mühlenhoff U, Lill R. 2004. The hydrogenase-like Narlp is essential for maturation of cytosolic and nuclear iron-sulphur proteins. EMBO J 23: $2105-2115$.

Banci L, Bertini I, Calderone V, Ciofi-Baffoni S, Giachetti A, Jaiswal D, Mikolajczyk M, Piccioli M, Winkelmann J. 2013. Molecular view of an electron transfer process essential for iron-sulfur protein biogenesis. Proc Natl Acad Sci 110: 7136-7141.

Bandyopadhyay S, Chandramouli K, Johnson MK. 2008a. Iron-sulfur cluster biosynthesis. Biochem Soc Trans 36: 1112-1119.

Bandyopadhyay S, Gama F, Molina-Navarro MM, Gualberto JM, Claxton R, Naik SG, Huynh BH, Herrero E, Jacquot JP, Johnson MK, et al. 2008b. Chloroplast monothiol glutaredoxins as scaffold proteins for the assembly and delivery of [2Fe-2S] clusters. EMBO J27: 1122-1133.
Becker T, Franckenberg S, Wickles S, Shoemaker CJ, Anger AM, Armache JP, Sieber H, Ungewickell C, Berninghausen O, Daberkow I, et al. 2012. Structural basis of highly conserved ribosome recycling in eukaryotes and archaea. Nature 482: 501-506.

Beinert H, Holm RH, Münck E. 1997. Iron-sulfur clusters: Nature's modular, multipurpose structures. Science 277: 653-659.

Bekri S, Kispal G, Lange H, Fitzsimons E, Tolmie J, Lill R, Bishop DF. 2000. Human ABC7 transporter: Gene structure and mutation causing $\mathrm{X}$-linked sideroblastic anemia with ataxia (XLSA/A) with disruption of cytosolic ironsulfur protein maturation. Blood 96: 3256-3264.

Biederbick A, Stehling O, Rösser R, Niggemeyer B, Nakai Y, Elsässer HP, Lill R. 2006. Role of human mitochondrial $\mathrm{Nfs} 1$ in cytosolic iron-sulfur protein biogenesis and iron regulation. Mol Cell Biol 26: 5675-5687.

Bonomi F, Iametti S, Morleo A, Ta D, Vickery LE. 2008. Studies on the mechanism of catalysis of iron-sulfur cluster transfer from IscU[2Fe2S] by $\mathrm{HscA} / \mathrm{HscB}$ chaperones. Biochemistry 47: 12795-12801.

Bridwell-Rabb J, Winn AM, Barondeau DP. 2011. Structurefunction analysis of Friedreich's ataxia mutants reveals determinants of frataxin binding and activation of the Fe-S assembly complex. Biochemistry 50: 7265-7274.

Bych K, Kerscher S, Netz DJ, Pierik AJ, Zwicker K, Huynen MA, Lill R, Brandt U, Balk J. 2008. The iron-sulphur protein Ind 1 is required for effective complex I assembly. EMBO J 27: 1736-1746.

Calvo SE, Tucker EJ, Compton AG, Kirby DM, Crawford G, Burtt NP, Rivas M, Guiducci C, Bruno DL, Goldberger OA, et al. 2010. High-throughput, pooled sequencing identifies mutations in NUBPL and FOXRED1 in human complex I deficiency. Nat Genet 42: 851-858.

Camaschella C, Campanella A, De Falco L, Boschetto L, Merlini R, Silvestri L, Levi S, Iolascon A. 2007. The human counterpart of zebrafish shiraz shows sideroblasticlike microcytic anemia and iron overload. Blood 110: 1353-1358.

Cameron JM, Janer A, Levandovskiy V, Mackay N, Rouault TA, Tong WH, Ogilvie I, Shoubridge EA, Robinson BH. 2011. Mutations in iron-sulfur cluster scaffold genes NFU1 and BOLA3 cause a fatal deficiency of multiple respiratory chain and 2-oxoacid dehydrogenase enzymes. Am J Hum Genet 89: 486-495.

Cavadini P, O’Neill HA, Benada O, Isaya G. 2002. Assembly and iron-binding properties of human frataxin, the protein deficient in Friedreich ataxia. Hum Mol Genet 11: 217-227.

Cazzola M, Invernizzi R. 2011. Ring sideroblasts and sideroblastic anemias. Haematologica 96: 789-792.

Chandramouli K, Johnson MK. 2006. HscA and HscB stimulate $[2 \mathrm{Fe}-2 \mathrm{~S}]$ cluster transfer from IscU to apoferredoxin in an ATP-dependent reaction. Biochemistry 45: 11087-11095.

Chen OS, Hemenway S, Kaplan J. 2002. Inhibition of Fe-S cluster biosynthesis decreases mitochondrial iron export: Evidence that Yfhlp affects Fe-S cluster synthesis. Proc Natl Acad Sci 99: 12321-12326.

Ciesielski SJ, Schilke BA, Osipiuk J, Bigelow L, Mulligan R, Majewska J, Joachimiak A, Marszalek J, Craig EA, Dutkiewicz R. 2012. Interaction of J-protein co-chaperone 
Jacl with Fe-S scaffold Isu is indispensable in vivo and conserved in evolution. J Mol Biol 417: 1-12.

Colin F, Martelli A, Clemancey M, Latour JM, Gambarelli S, Zeppieri L, Birck C, Page A, Puccio H, Ollagnier de Choudens S. 2013. Mammalian frataxin controls sulfur production and iron entry during de novo Fe4S4 cluster assembly. J Am Chem Soc 135: 733-740.

Crooks DR, Jeong SY, Tong WH, Ghosh MC, Olivierre H, Haller RG, Rouault TA. 2012. Tissue specificity of a human mitochondrial disease: Differentiation-enhanced mis-splicing of the Fe-S scaffold gene ISCU renders patient cells more sensitive to oxidative stress in ISCU myopathy. J Biol Chem 287: 40119-40130.

Embley TM, Martin W. 2006. Eukaryotic evolution, changes and challenges. Nature 440: 623-630.

Gari K, Leon Ortiz AM, Borel V, Flynn H, Skehel JM, Boulton SJ. 2012. MMS19 links cytoplasmic iron-sulfur cluster assembly to DNA metabolism. Science 337: 243-245.

Gelling C, Dawes IW, Richhardt N, Lill R, Mühlenhoff U. 2008. Mitochondrial Iba57p is required for Fe/S cluster formation on aconitase and activation of radical SAM enzymes. Mol Cell Biol 28: 1851-1861.

Gerber J, Mühlenhoff U, Lill R. 2003. An interaction between frataxin and Isul/Nfs1 that is crucial for $\mathrm{Fe} / \mathrm{S}$ cluster synthesis on Isu1. EMBO Rep 4: 906-911.

Gerber J, Neumann K, Prohl C, Mühlenhoff U, Lill R. 2004. The yeast scaffold proteins Isulp and Isu2p are required inside mitochondria for maturation of cytosolic $\mathrm{Fe} / \mathrm{S}$ proteins. Mol Cell Biol 24: 4848-4857.

Goldberg AV, Molik S, Tsaousis AD, Neumann K, Kuhnke G, Delbac F, Vivares CP, Hirt RP, Lill R, Embley TM. 2008. Localization and functionality of microsporidian ironsulphur cluster assembly proteins. Nature 452: 624-628.

Gupta V, Sendra M, Naik SG, Chahal HK, Huynh BH, Outten FW, Fontecave M, Ollagnier de Choudens S. 2009. Native Escherichia coli SufA, coexpressed with SufBCDSE, purifies as a $[2 \mathrm{Fe}-2 \mathrm{~S}]$ protein and acts as an Fe-S transporter to Fe-S target enzymes. JAm Chem Soc 131: 61496153.

Haunhorst P, Hanschmann EM, Bräutigam L, Stehling O, Hoffmann B, Mühlenhoff U, Lill R, Berndt C, Lillig CH. 2013. Crucial function of vertebrate glutaredoxin 3 (PICOT) in iron homeostasis and hemoglobin maturation. Mol Biol Cell 24: 1895-1903.

Hu Y, Ribbe MW. 2012. Nitrogenase assembly. Biochim Biophys Acta doi: 10.1016/j.bbabio.2012.12.001.

Johnson DC, Dean DR, Smith AD, Johnson MK. 2005. Structure, function and formation of biological ironsulfur clusters. Ann Rev Biochem 74: 247-281.

Kampinga HH, Craig EA. 2010. The HSP70 chaperone machinery: J proteins as drivers of functional specificity. Nat Rev Mol Cell Biol 11: 579-592.

Karthikeyan G, Lewis LK, Resnick MA. 2002. The mitochondrial protein frataxin prevents nuclear damage. Hum Mol Genet 11: 1351-1362.

Kispal G, Csere P, Prohl C, Lill R. 1999. The mitochondrial proteins Atmlp and Nfs1p are required for biogenesis of cytosolic Fe/S proteins. EMBO J 18: 3981-3989.

Kispal G, Sipos K, Lange H, Fekete Z, Bedekovics T, Janaky T, Bassler J, Aguilar Netz DJ, Balk J, Rotte C, et al. 2005. Biogenesis of cytosolic ribosomes requires the essential iron-sulphur protein Rlilp and mitochondria. EMBO J 24: 589-598.

Klinge S, Hirst J, Maman JD, Krude T, Pellegrini L. 2007. An iron-sulfur domain of the eukaryotic primase is essential for RNA primer synthesis. Nat Struct Mol Biol 14: 875877.

Kumanovics A, Chen O, Li L, Bagley D, Adkins E, Lin H, Dingra NN, Outten CE, Keller G, Winge D, et al. 2008. Identification of FRA1 and FRA2 as genes involved in regulating the yeast iron regulon in response to decreased mitochondrial iron-sulfur cluster synthesis. J Biol Chem 283: 10276-10286.

Lange H, Kaut A, Kispal G, Lill R. 2000. A mitochondrial ferredoxin is essential for biogenesis of cellular iron-sulfur proteins. Proc Natl Acad Sci 97: 1050-1055.

Lanz ND, Booker SJ. 2012. Identification and function of auxiliary iron-sulfur clusters in radical SAM enzymes. Biochim Biophys Acta 1824: 1196-1212.

Li H, Outten CE. 2012. Monothiol CGFS glutaredoxins and BolA-like proteins: [2Fe-2S] binding partners in iron homeostasis. Biochemistry 51: 4377-4389.

Lill R. 2009. Function and biogenesis iron-sulphur proteins. Nature 460: 831-838.

Lill R, Mühlenhoff U. 2005. Iron-sulfur protein biogenesis in eukaryotes. Trends Biochem Sci 30: 133-141.

Lill R, Mühlenhoff U. 2008. Maturation of iron-sulfur proteins in eukaryotes: Mechanisms, connected processes, and diseases. Annu Rev Biochem 77: 669-700.

Lill R, Hoffmann B, Molik S, Pierik AJ, Rietzschel N, Stehling O, Uzarska MA, Webert H, Wilbrecht C, Mühlenhoff U. 2012. The role of mitochondria in cellular iron-sulfur protein biogenesis and iron metabolism. Biochim Biophys Acta 1823: 1491-1508.

Long S, Changmai P, Tsaousis AD, Skalicky T, Verner Z, Wen YZ, Roger AJ, Lukes J. 2011. Stage-specific requirement for Isal and Isa2 proteins in the mitochondrion of Trypanosoma brucei and heterologous rescue by human and Blastocystis orthologues. Mol Microbiol 81: 1403-1418.

Lu J, Bitoun JP, Tan G, Wang W, Min W, Ding H. 2010. Ironbinding activity of human iron-sulfur cluster assembly protein hIscA1. Biochem J 428: 125-131.

Mapolelo DT, Zhang B, Randeniya S, Albetel AN, Li H, Couturier J, Outten CE, Rouhier N, Johnson MK. 2013. Monothiol glutaredoxins and A-type proteins: Partners in Fe-S cluster trafficking. Dalton Trans 42: 3107-3115.

Miao R, Kim H, Koppolu UM, Ellis EA, Scott RA, Lindahl PA. 2009. Biophysical characterization of the iron in mitochondria from Atmlp-depleted Saccharomyces cerevisiae. Biochemistry 48: 9556-9568.

Mochel F, Knight MA, Tong WH, Hernandez D, Ayyad K, Taivassalo T, Andersen PM, Singleton A, Rouault TA, Fischbeck KH, et al. 2008. Splice mutation in the ironsulfur cluster scaffold protein ISCU causes myopathy with exercise intolerance. Am J Hum Genet 82: 652-660.

Molik S, Lill R. 2012. Role of mitosomes in cellular ironsulfur protein biogenesis. J Endocyt Cell Res 23: 77-85.

Mühlenhoff U, Gerber J, Richhardt N, Lill R. 2003. Components involved in assembly and dislocation of ironsulfur clusters on the scaffold protein Isulp. EMBO J 22: $4815-4825$. 
Mühlenhoff U, Balk J, Richhardt N, Kaiser JT, Sipos K, Kispal G, Lill R. 2004. Functional characterization of the eukaryotic cysteine desulfurase Nfs1p from Saccharomyces cerevisiae. J Biol Chem 279: 36906-36915.

Mühlenhoff U, Gerl MJ, Flauger B, Pirner HM, Balser S, Richhardt N, Lill R, Stolz J. 2007. The ISC proteins Isal and Isa 2 are required for the function but not for the de novo synthesis of the $\mathrm{Fe} / \mathrm{S}$ clusters of biotin synthase in Saccharomyces cerevisiae. Eukaryot Cell 6: 495-504.

Mühlenhoff U, Molik S, Godoy JR, Uzarska MA, Richter N, Seubert A, Zhang Y, Stubbe J, Pierrel F, Herrero E, et al. 2010. Cytosolic monothiol glutaredoxins function in intracellular iron sensing and trafficking via their bound iron-sulfur cluster. Cell Metab 12: 373-385.

Mühlenhoff U, Richter N, Pines O, Pierik AJ, Lill R. 2011. Specialized function of yeast Isa 1 and Isa2 proteins in the maturation of mitochondrial $[4 \mathrm{Fe}-4 \mathrm{~S}]$ proteins. J Biol Chem 286: 41205-41216.

Müller M, Mentel M, van Hellemond JJ, Henze K, Woehle C Gould SB, Yu RY, van der Giezen M, Tielens AG, Martin WF. 2012. Biochemistry and evolution of anaerobic energy metabolism in eukaryotes. Microbiol Mol Biol Rev 76: 444-495.

Nakai Y, Nakai M, Hayashi H, Kagamiyama H. 2001. Nuclear localization of yeast $\mathrm{Nfs} 1 \mathrm{p}$ is required for cell survival. $J$ Biol Chem 276: 8314-8320.

Navarro-Sastre A, Tort F, Stehling O, Uzarska MA, Arranz JA, Del Toro M, Labayru MT, Landa J, Font A, GarciaVilloria J, et al. 2011. A fatal mitochondrial disease is associated with defective NFU1 function in the maturation of a subset of mitochondrial Fe-S proteins. Am J Hum Genet 89: 656-667.

Netz DJ, Pierik AJ, Stümpfig M, Mühlenhoff U, Lill R. 2007. The Cfd1-Nbp35 complex acts as a scaffold for ironsulfur protein assembly in the yeast cytosol. Nat Chem Biol 3: 278-286.

Netz DJ, Stümpfig M, Dore C, Mühlenhoff U, Pierik AJ, Lill R. 2010. Tah18 transfers electrons to Dre2 in cytosolic iron-sulfur protein biogenesis. Nat Chem Biol 6: 758 765.

Netz DJ, Pierik AJ, Stümpfig M, Bill E, Sharma AK, Pallesen LJ, Walden WE, Lill R. 2012a. A bridging [4Fe-4S] cluster and nucleotide binding are essential for the function of the Cfd1-Nbp35 complex as a scaffold in iron-sulfur protein maturation. J Biol Chem 287: 12365-12378

Netz DJ, Stith CM, Stümpfig M, Kopf G, Vogel D, Genau HM, Stodola JL, Lill R, Burgers PM, Pierik AJ. 2012b. Eukaryotic DNA polymerases require an iron-sulfur cluster for the formation of active complexes. Nat Chem Biol 8: 125-132.

Nordin A, Larsson E, Holmberg M. 2012. The defective splicing caused by the ISCU intron mutation in patients with myopathy with lactic acidosis is repressed by PTBP1 but can be derepressed by IGF2BP1. Hum Mutat 33: 467470.

Olsson A, Lind L, Thornell LE, Holmberg M. 2008. Myopathy with lactic acidosis is linked to chromosome $12 \mathrm{q} 23.3-24.11$ and caused by an intron mutation in the ISCU gene resulting in a splicing defect. Hum Mol Genet 17: 1666-1667.
Peters JW, Broderick JB. 2012. Emerging paradigms for complex iron-sulfur cofactor assembly and insertion. Аnпu Rev Biochem 81: 429-450.

Philpott CC, Leidgens S, Frey AG. 2012. Metabolic remodeling in iron-deficient fungi. Biochim Biophys Acta 1823: 1509-1520.

Pondarre C, Antiochos BB, Campagna DR, Clarke SL, Greer EL, Deck KM, McDonald A, Han AP, Medlock A, Kutok JL, et al. 2006. The mitochondrial ATP-binding cassette transporter Abcb7 is essential in mice and participates in cytosolic iron-sulphur cluster biogenesis. Hum $\mathrm{Mol} \mathrm{Ge}$ net 15: 953-964.

Pukszta S, Schilke B, Dutkiewicz R, Kominek J, Moczulska K, Stepien B, Reitenga KG, Bujnicki JM, Williams B, Craig EA, et al. 2010. Co-evolution-driven switch of Jprotein specificity towards an Hsp70 partner. EMBO Rep 11: 360-365.

Py B, Barras F. 2010. Building Fe-S proteins: Bacterial strategies. Nat Rev Microbiol 8: 436-446.

Radisky DC, Babcock MC, Kaplan J. 1999. The yeast frataxin homologue mediates mitochondrial iron efflux. Evidence for a mitochondrial iron cycle. J Biol Chem 274: 4497-4499.

Rodriguez-Manzaneque MT, Tamarit J, Belli G, Ros J, Herrero E. 2002. Grx5 is a mitochondrial glutaredoxin required for the activity of iron/sulfur enzymes. Mol Biol Cell 13: 1109-1121.

Rouault TA. 2012. Biogenesis of iron-sulfur clusters in mammalian cells: New insights and relevance to human disease. Dis Model Mech 5: 155-164.

Rudolf J, Makrantoni V, Ingledew WJ, Stark MJ, White MF. 2006. The DNA repair helicases XPD and FancJ have essential iron-sulfur domains. Mol Cell 23: 801-808.

Schilke B, Voisine C, Beinert H, Craig E. 1999. Evidence for a conserved system for iron metabolism in the mitochondria of Saccharomyces cerevisiae. Proc Natl Acad Sci 6: 10206-10211.

Schilke B, Williams B, Knieszner H, Pukszta S, D'Silva P, Craig EA, Marszalek J. 2006. Evolution of mitochondrial chaperones utilized in Fe-S cluster biogenesis. Curr Biol 16: $1660-1665$.

Schmucker S, Puccio H. 2010. Understanding the molecular mechanisms of Friedreich's ataxia to develop therapeutic approaches. Hum Mol Genet 19: R103-R110.

Schmucker S, Martelli A, Colin F, Page A, WattenhoferDonze M, Reutenauer L, Puccio H. 2011. Mammalian frataxin: An essential function for cellular viability through an interaction with a preformed ISCU/NFS1/ ISD11 iron-sulfur assembly complex. PLoS ONE 6: e16199.

Schrettl M, Haas H. 2011. Iron homeostasis-Achilles' heel of Aspergillus fumigatus? Curr Opin Microbiol 14: 400405.

Shakamuri P, Zhang B, Johnson MK. 2012. Monothiol glutaredoxins function in storing and transporting [Fe2S2] clusters assembled on IscU scaffold proteins. J Am Chem Soc 134: 15213-15216.

Sharma AK, Pallesen LJ, Spang RJ, Walden WE. 2010. Cytosolic iron-sulfur cluster assembly (CIA) system: Factors, mechanism, and relevance to cellular iron regulation. J Biol Chem 285: 26745-26751. 
Sheftel AD, Stehling O, Pierik AJ, Netz DJ, Kerscher S, Elsässer HP, Wittig I, Balk J, Brandt U, Lill R. 2009. Human Ind1, an iron-sulfur cluster assembly factor for respiratory complex I. Mol Cell Biol 29: 6059-6073.

Sheftel A, Stehling O, Lill R. 2010a. Iron-sulfur proteins in health and disease. Trends Endocrinol Metab 21: 302314.

Sheftel AD, Stehling O, Pierik AJ, Elsässer HP, Mühlenhoff U, Webert H, Hobler A, Hannemann F, Bernhardt R, Lill R. 2010b. Humans possess two mitochondrial ferredoxins, $\mathrm{Fdx} 1$ and $\mathrm{Fdx} 2$, with distinct roles in steroidogenesis, heme, and Fe/S cluster biosynthesis. Proc Natl Acad Sci 107: $11775-11780$.

Sheftel AD, Wilbrecht C, Stehling O, Niggemeyer B, Elsässer HP, Mühlenhoff U, Lill R. 2012. The human mitochondrial ISCA1, ISCA2, and IBA57 proteins are required for [4Fe-4S] protein maturation. Mol Biol Cell 23: $1157-$ 1166.

Shi Y, Ghosh MC, Tong WH, Rouault TA. 2009. Human ISD11 is essential for both iron-sulfur cluster assembly and maintenance of normal cellular iron homeostasis. Hum Mol Genet 18: 3014-3025.

Song D, Lee FS. 2008. A role for IOP1 in mammalian cytosolic iron-sulfur protein biogenesis. J Biol Chem 283: 9231-9238.

Song D, Tu Z, Lee FS. 2009. Human ISCA1 interacts with IOP1/NARFL and functions in both cytosolic and mitochondrial iron-sulfur protein biogenesis. J Biol Chem 284: 35297-35307.

Srinivasan V, Netz DJA, Webert H, Mascarenhas J, Pierik AJ, Michel H, Lill R. 2007. Structure of the yeast WD40 domain protein Cial, a component acting late in iron-sulfur protein biogenesis. Structure 15: 1246-1257.

Stehling O, Vashisht AA, Mascarenhas J, Jonsson ZO, Sharma T, Netz DJ, Pierik AJ, Wohlschlegel JA, Lill R. 2012. MMS19 assembles iron-sulfur proteins required for DNA metabolism and genomic integrity. Science 337: 195-199.

Stemmler TL, Lesuisse E, Pain D, Dancis A. 2010. Frataxin and mitochondrial FeS cluster biogenesis. J Biol Chem 285: 26737-26743.

Thierbach R, Drewes G, Fusser M, Voigt A, Kuhlow D, Blume U, Schulz TJ, Reiche C, Glatt H, Epe B, et al. 2010. The Friedreich's ataxia protein frataxin modulates DNA base excision repair in prokaryotes and mammals. Biochem J 432: 165-172.

Thompson JW, Bruick RK. 2012. Protein degradation and iron homeostasis. Biochim Biophys Acta 1823: $1484-$ 1490.

Tong WH, Jameson GN, Huynh BH, Rouault TA. 2003. Subcellular compartmentalization of human Nfu, an iron-sulfur cluster scaffold protein, and its ability to assemble a [4Fe-4S] cluster. Proc Natl Acad Sci 100: 9762-9767.

Tovar J, Leon-Avila G, Sanchez LB, Sutak R, Tachezy J, Van Der Giezen M, Hernandez M, Muller M, Lucocq JM. 2003. Mitochondrial remnant organelles of Giardia function in iron-sulphur protein maturation. Nature $\mathbf{4 2 6}$ $172-176$.

Tsai CL, Barondeau DP. 2010. Human frataxin is an allosteric switch that activates the Fe-S cluster biosynthetic complex. Biochemistry 49: 9132-9139.
Uhrigshardt H, Singh A, Kovtunovych G, Ghosh M, Rouault TA. 2010. Characterization of the human HSC20, an unusual DnaJ type III protein, involved in iron-sulfur cluster biogenesis. Hum Mol Genet 19: 3816-3834.

Urzica E, Pierik AJ, Muhlenhoff U, Lill R. 2009. Crucial role of conserved cysteine residues in the assembly of two iron-sulfur clusters on the CIA protein Nar1. Biochemistry 48: 4946-4958.

Uzarska MA, Dutkiewicz R, Freibert SA, Lill R, Muhlenhoff U. 2013. The mitochondrial Hsp70 chaperone Ssq1 facilitates $\mathrm{Fe} / \mathrm{S}$ cluster transfer from Isu1 to Grx 5 by complex formation. Mol Biol Cell 24: 1830-1841.

van der Giezen M. 2009. Hydrogenosomes and mitosomes: Conservation and evolution of functions. J Eukaryot Microbiol 56: 221-231.

Vickery LE, Cupp-Vickery JR. 2007. Molecular chaperones $\mathrm{HscA} / \mathrm{Ssq} 1$ and $\mathrm{HscB} / \mathrm{Jacl}$ and their roles in iron-sulfur protein maturation. Crit Rev Biochem Mol Biol 42: 95111.

Waller JC, Alvarez S, Naponelli V, Lara-Nunez A, Blaby IK, Da Silva V, Ziemak MJ, Vickers TJ, Beverley SM, Edison AS, et al. 2010. A role for tetrahydrofolates in the metabolism of iron-sulfur clusters in all domains of life. Proc Natl Acad Sci 107: 10412-10417.

Wang W, Huang H, Tan G, Si F, Liu M, Landry AP, Lu J, Ding H. 2010. In vivo evidence for the iron-binding activity of an iron-sulfur cluster assembly protein IscA in Escherichia coli. Biochem J 432: 429-436.

Weerapana E, Wang C, Simon GM, Richter F, Khare S, Dillon MB, Bachovchin DA, Mowen K, Baker D, Cravatt BF. 2010. Quantitative reactivity profiling predicts functional cysteines in proteomes. Nature 468: 790-795.

Wiedemann N, Urzica E, Guiard B, Müller H, Lohaus C, Meyer HE, Ryan MT, Meisinger C, Mühlenhoff U, Lill R, et al. 2006. Essential role of Isd11 in iron-sulfur cluster synthesis on Isu scaffold proteins. EMBO J 25: 184-195.

Wingert RA, Galloway JL, Barut B, Foott H, Fraenkel P, Axe JL, Weber GJ, Dooley K, Davidson AJ, Schmid B, et al. 2005. Deficiency of glutaredoxin 5 reveals Fe-S clusters are required for vertebrate haem synthesis. Nature 436: 1035-1039.

Yarunin A, Panse V, Petfalski E, Tollervey D, Hurt E. 2005. Functional link between ribosome formation and biogenesis of iron-sulfur proteins. EMBO J 24: 580-588.

Ye H, Jeong SY, Ghosh MC, Kovtunovych G, Silvestri L, Ortillo D, Uchida N, Tisdale J, Camaschella C, Rouault TA. 2010. Glutaredoxin 5 deficiency causes sideroblastic anemia by specifically impairing heme biosynthesis and depleting cytosolic iron in human erythroblasts. J Clin Invest 120: 1749-1761.

Zhang Y, Lyver ER, Nakamaru-Ogiso E, Yoon H, Amutha B, Lee D-W, Bi E, Ohnishi T, Daldal F, Pain D, et al. 2008. Dre2, a conserved eukaryotic $\mathrm{Fe} / \mathrm{S}$ cluster protein, functions in cytosolic $\mathrm{Fe} / \mathrm{S}$ protein biogenesis. Mol Cell Biol 28: 5569-5582.

Zhang Y, Liu L, Wu X, An X, Stubbe J, Huang M. 2011. Investigation of in vivo diferric tyrosyl radical formation in Saccharomyces cerevisiae Rnr2 protein: Requirement of Rnr4 and contribution of Grx3/4 AND Dre2 proteins. J Biol Chem 286: 41499-41509. 


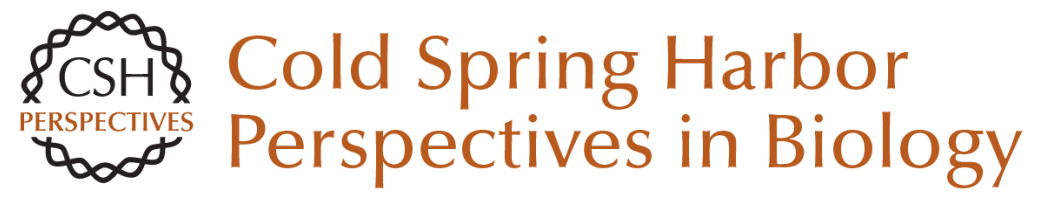

\section{The Role of Mitochondria in Cellular Iron-Sulfur Protein Biogenesis: Mechanisms, Connected Processes, and Diseases}

Oliver Stehling and Roland Lill

Cold Spring Harb Perspect Biol 2013; doi: 10.1101/cshperspect.a011312

Subject Collection Mitochondria

Altered Sulfide $\left(\mathrm{H}_{2} \mathrm{~S}\right)$ Metabolism in Ethylmalonic Encephalopathy

Valeria Tiranti and Massimo Zeviani

Mitochondrial DNA Genetics and the

Heteroplasmy Conundrum in Evolution and

Disease

Douglas C. Wallace and Dimitra Chalkia

The Role of Mitochondria in Cellular Iron-Sulfur

Protein Biogenesis: Mechanisms, Connected

Processes, and Diseases

Oliver Stehling and Roland Lill

Mechanisms of Mitochondrial Fission and Fusion Alexander M. van der Bliek, Qinfang Shen and Sumihiro Kawajiri

The Mitochondrial Nucleoid: Integrating Mitochondrial DNA into Cellular Homeostasis

Robert Gilkerson, Liliana Bravo, Iraselia Garcia, et al.

Relevance of Mitochondrial Genetics and

Metabolism in Cancer Development

Giuseppe Gasparre, Anna Maria Porcelli, Giorgio

Lenaz, et al.

Mitochondrial Quality Control Mediated by PINK1 and Parkin: Links to Parkinsonism

Derek Narendra, John E. Walker and Richard Youle
Where Killers Meet--Permeabilization of the Outer

Mitochondrial Membrane during Apoptosis

Tom Bender and Jean-Claude Martinou

Mitochondrial Biogenesis through Activation of

Nuclear Signaling Proteins

John E. Dominy and Pere Puigserver

Mitochondrial Trafficking in Neurons Thomas L. Schwarz

Mitochondrial Dysfunction and Defective Autophagy in the Pathogenesis of Collagen VI Muscular Dystrophies

Paolo Bernardi and Paolo Bonaldo

Clinical and Molecular Features of POLG-Related Mitochondrial Disease

Jeffrey D. Stumpf, Russell P. Saneto and William C. Copeland

Mitochondrial Metabolism, Sirtuins, and Aging Michael N. Sack and Toren Finkel

Mechanisms of Protein Sorting in Mitochondria Diana Stojanovski, Maria Bohnert, Nikolaus Pfanner, et al.

For additional articles in this collection, see http://cshperspectives.cshlp.org/cgi/collection/

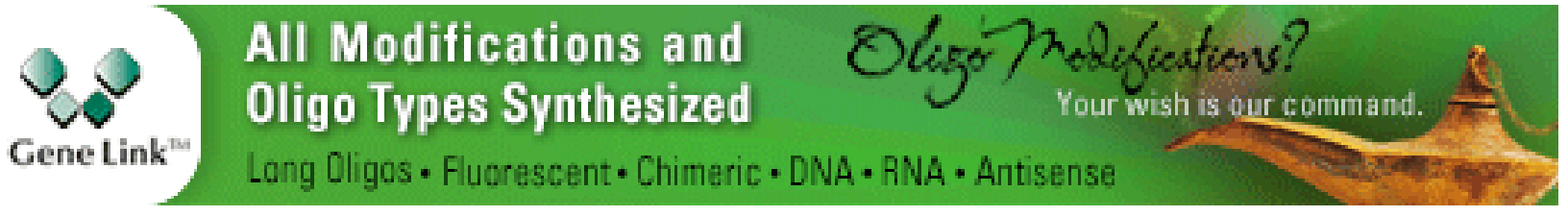




\section{Mitochondrial Evolution}

Michael W. Gray

For additional articles in this collection, see http://cshperspectives.cshlp.org/cgi/collection/

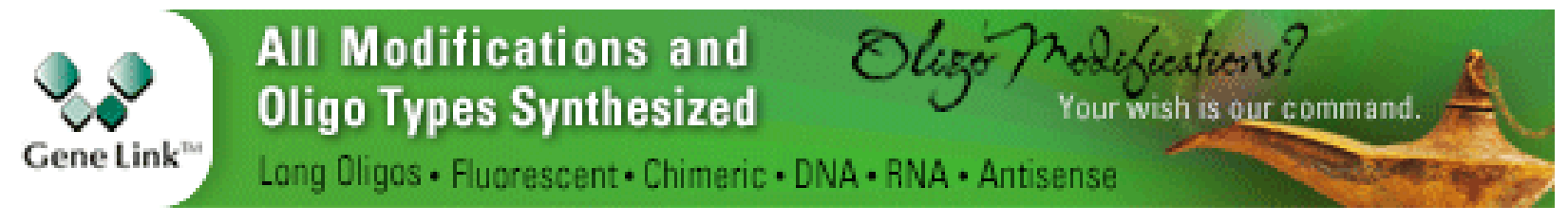

Copyright @ 2013 Cold Spring Harbor Laboratory Press; all rights reserved 